\title{
Retraction
}

\section{c-FLIPL enhances anti-apoptotic Akt functions by modulation of Gsk3 $\beta$ activity}

\author{
C Quintavalle, M Incoronato, L Puca, M Acunzo, C Zanca, G Romano, M Garofalo, M laboni, CM Croce and G Condorelli
}

Cell Death and Differentiation (2017) 24, 1134; doi:10.1038/cdd.2017.7; published online 20 January 2017

Retraction to: Cell Death and Differentiation 2010; 17: 1908-1916. doi:10.1038/cdd.2010.65.

The Editors have agreed to retract the above article in Cell Death and Differentiation (2010) 17, 1908-1916, due to the use of a mismatched image in control lanes of Figure 2c. However, the authors wish to note that the results reported in
Figure $2 \mathrm{c}$ have been reported and confirmed in Figure $2 \mathrm{f}$ of the same manuscript. The authors are convinced of the reproducibility of the data presented, which will be resubmitted for publication using the correct panel for Figure 2c. The authors apologize to the scientific community for any inconveniences caused. 